The role of resident cells during the lipopolysaccharide (LPS)-induced neutrophil recruitment into rat air pouches was investigated. In this model, LPS (Escherichia coli, O55: B5 strain; 2$2000 \mathrm{ng}$ ) induced a dose- and time-dependent neutrophil recruitment accompanied by the generation of a tumour necrosis factor- $\alpha$ (TNF $\alpha)$-like activity. Dexamethasone $(0.05-5 \mu \mathrm{g})$ and cycloheximide $(6 \mathrm{ng})$, injected $2 \mathrm{~h}$ before LPS in to the pouches, inhibited the neutrophil recruitment and the generation of the TNF $\alpha$-like activity, while the H1-receptor antagonist mepyramine (1 and $4 \mathrm{mg} / \mathrm{kg}$, i.p., $0.5 \mathrm{~h}$ before LPS) and the PAFreceptor antagonist WEB $2170(0.05$ and $1 \mathrm{mg} / \mathrm{kg}$, i.p., $0.5 \mathrm{~h}$ before LPS) had no effect. Purified alveolar macrophages (AM) were used to replenish the pouches of cycloheximide-treated recipient rats. AM provided by PBS-treated animals led to the recovery of the LPS-induced neutrophil recruitment and of the TNF $\alpha$-like formation contrasting with those from cycloheximide-treated animals $(1 \mathrm{mg} / \mathrm{kg}$, i.p.). When delivered in situ, liposome-encapsulated clodronate, a macrophage depletor, significantly impaired both the LPSinduced neutrophil recruitment and the TNF $\alpha$-like activity. An anti-murine TNF $\alpha$ polyclonal antibody ( $0.5 \mathrm{~h}$ before LPS) was also effective. These results emphasize the pivotal role of macrophages for LPS-induced neutrophil recruitment via the formation of TNF $\alpha$.

Key words: Rat air pouch, Lipopolysaccharide, Neutrophil recruitment, Macrophage, Tumour necrosis factor- $\alpha$

\section{The LPS-induced neutrophil recruitment into rat air pouches is mediated by TNF $\alpha$ : likely macrophage origin}

\author{
C-D. Arreto ${ }^{1,2, C A}$, C. Dumarey ${ }^{1}, \mathrm{M}-\mathrm{A}$. Nahori $^{1}$ and \\ B. B. Vargaftig ${ }^{1}$
}

${ }^{1}$ Unite de Pharmacologie Cellulaire, Institut Pasteur; 25, rue du Dr Roux, 75724 Paris Cedex 15;

${ }^{2}$ Département de Pharmacologie, Faculté de

Chirurgie Dentaire, Universite René Descartes,

Paris V, France

\author{
${ }^{\mathrm{CA}}$ Corresponding Author \\ Tel: $(+33) 45688682$ \\ Fax: $(+33) 45688703$ \\ Email: 〈vargaftig@pasteurfr〉
}

\section{Introduction}

Leukocyte recruitment ${ }^{1,2}$ and the formation of pro-inflammatory mediators, including different cytokines, are the hallmark of an inflammatory response. The latter is characterized by vasodilatation, rapidly followed by neutrophil adhesion to endothelium and migration into the perivascular connective tissue.

In vitro studies have shown that the bacterial endotoxin (lipopolysaccharide, LPS) is not by itself a chemotactic factor, ${ }^{3}$ even though LPS may interact with neutrophils via CD14 and the LPS-binding protein (LBP) to express CR3 activity which mediates neutrophil adhesion. ${ }^{4}, 5$ In fact, local cell targets seem to be more relevant in vivo and in particular, resident macrophages are believed to play a pivotal role in the recognition and the transduction of the effects of LPS (for review, see Manthey and Vogel ${ }^{6}$ ) since they produce the chemotactic mediators IL- $1 \alpha$ and $\beta$, TNF $\alpha$, IL- 8 and MP- 1 and 2 as well as $\mathrm{LTB}_{4}$ and PAF. Furthermore, LPS elicits a selective and transient cycloheximide-dependent collagenase synthesis by macrophages, providing thus another potential tissue damaging factor. ${ }^{7}$

Initially described as a potent inflammatory cytokine derived from LPS-activated macrophages, TNFo may also account for neutropenia, neutrophilia, ${ }^{8,9}$ and neutrophil recruitment $2^{2,10-12}$ and activation. 13,14 TNFo also induces the expression of cell surface molecules, leading to adherence on endothelial cells. ${ }^{15}$ As an early cytokine, TNF $\alpha$ is released extracellularly within $15 \mathrm{~min}$ after its gene transcription upon exposure to inflammatory stimuli. ${ }^{16}$ Its broad spectrum of activities and the amounts produced by macrophages stimulated by various products (up to $2 \%$ of their total biosynthesis) suggest that TNF $\alpha$ is an important mediator of LPS-induced inflammatory response. ${ }^{17}$ Glucocorticoids such as dexamethasone inhibit the production of circulating TNF $\alpha$ in mice, rats $^{18}$ and guinea-pigs ${ }^{19}$ treated with LPS. Dexamethasone also alters the phagocytic functions of 
macrophages in vitro ${ }^{20}$ and contributes to protect rat macrophages against LPS-induced $\mathrm{TNF} \alpha$ production in vitro, even though less so in vivo.

The cutaneous air pouch provides a virtual cavity which can be tailored as a migration chamber covered innerly with a lining membrane, the facsimile synovium. ${ }^{22}$ Since the walls of the pouch are formed by macrophages and fibroblasts and a few mastocytes, we took advantage of this model to study the mode of action of LPS. Because of the potential damage engendered by the neutrophil towards connective tissue, ${ }^{23}$ we investigated the dependency of LPS-induced neutrophil emigration upon resident cells and bring evidence that macrophages and TNF $\alpha$ are respectively the target and the mediator of neutrophil recruitment following LPS injection into rat air pouches.

\section{Materials and Methods}

\section{Animals}

Brown-Norway rats (200-250 g) (Iffa Credo, France) were allowed to take food and drink ad libitum at room temperature.

\section{Rat air pouch}

The air pouch was induced according to Edwards et al. ${ }^{22}$ At day 0, rats were anaesthetized with ketamine $(50 \mathrm{mg} / \mathrm{kg}, \mathrm{i} . \mathrm{m}$.) and their dorsum was thoroughly shaved and gently disinfected with ethanol $70^{\circ}$. Syringes and needles were one-purpose material. Twenty $\mathrm{ml}$ of sterile air taken under a laminar flux hood were injected subcutaneously with a gauge $26 \mathrm{G} \times 0.5$ "; $0.45 \times 12$ needle; thus, disruption of the underlying cutaneous connective tissue allowed to make an air-full cavity. At day 5, $10 \mathrm{ml}$ of sterile air were injected in similar conditions in order to maintain pouch patency. At day 7 , the pouches were injected with LPS $(2-2000 \mathrm{ng} / \mathrm{ml})$ under a volume of $1 \mathrm{ml}$. Control animals were injected with the same volume of the LPS vehicle, i.e. phosphate buffered saline (PBS) without $\mathrm{Ca}^{2+}$ nor $\mathrm{Mg}^{2+}$.

\section{Neutrophil migration assessment}

At various times ( $2 \mathrm{~h}, 24 \mathrm{~h}, 48 \mathrm{~h}$ and $96 \mathrm{~h})$ after LPS injection, animals were killed with an overdose of sodium penthiobarbitone. Four $\mathrm{ml}$ of heparinized $\mathrm{PBS}$ solution $(5 \mathrm{IU} / \mathrm{ml}$ ) were injected into the pouch in order to wash the cavity by a gentle massage. The washing solu- tion which was recovered at over $95 \%$ was collected into $6 \mathrm{ml}$-polypropylene round bottom tubes (Falcon ${ }^{\circ} 2063$, sterile/gamma irradiated) stored on an ice bath.

Injection of the mastocyte degranulating agent compound 48/80, under $1 \mathrm{ml}(250$ $\mu \mathrm{g} / \mathrm{ml}$ ) into the rat air pouch followed the same procedures. This concentration was chosen for its ability to induce granulocyte infiltration in the mouse skin. ${ }^{24}$

Leukocyte and differential counts were performed with a cell counter (Coulter $\left.{ }^{(}\right)$) and a Cytospin (Hettich Universal ${ }^{\complement}$ ), respectively, and allowed to calculate the total number of leukocyte neutrophils recovered.

One $\mathrm{ml}$ aliquots prepared from the pouch washing were centrifuged $(400 \mathrm{~g}, 10 \mathrm{~min}$ at $4^{\circ} \mathrm{C}$ ), pellets and aliquoted supernatants being kept at $-40^{\circ} \mathrm{C}$ until further analysis.

\section{TNF $\alpha$ assay}

$\mathrm{TNF} \alpha$ production was determined directly in the supernatant using the $\mathrm{TNF} \alpha$ sensitive cell line WEHI-164. Cells were plated out in 96-well plates $\left(8 \times 10^{4}\right.$ cells $\left./ 50 \mu \mathrm{l} / \mathrm{well}\right)$ and the samples $(50 \mu \mathrm{l} / \mathrm{well})$ or the human recombinant TNFo (hr-TNFo) standards $\left(1-10^{6} \mathrm{U} / \mathrm{ml}\right.$ hr-TNFo, $50 \mu \mathrm{l} /$ well) were added. After $24 \mathrm{~h}$ incubation $\left(37^{\circ} \mathrm{C}, 7.5 \% \mathrm{CO}_{2}\right)$, MTT (tetrazolium salt, Sigma, USA) was added $(0.125 \mathrm{mg} / \mathrm{well})$. After an incubation of $4 \mathrm{~h}$, the cells were lysed with buffer (20\% sodium dodecyl sulphate (SDS) in $50 \%$ N,N-dimethylformamide (DMF), $\mathrm{pH} 4.7,100 \mu \mathrm{l} / \mathrm{well}$ ) for $18 \mathrm{~h}$. The difference of absorbances measured at $550 \mathrm{~nm}$ and $630 \mathrm{~nm}$ with an EUSA reader (Dynatech MR5000) allowed to evaluate the TNFo-like activity.

\section{Modulation of neutrophil recruitment}

In some experiments, cycloheximide $(6 \mathrm{ng} / \mathrm{ml})$ or dexamethasone $(0.5-5 \mu \mathrm{g} / \mathrm{ml})$ were injected into the pouch $2 \mathrm{~h}$ before LPS $(200 \mathrm{ng} / \mathrm{ml})$ under a volume of $1 \mathrm{ml}$. In other experiments, animals received mepyramine $(1-4 \mathrm{mg} / \mathrm{kg})$ i.p. $30-45 \mathrm{~min}$ before LPS was injected into the pouch.

An anti-murine TNFo immunoglobulin preparation was prepared as follows. Female $\mathrm{HY} /$ CR rabbits (2500 g; Charles River, St Aubin les Elboeufs, France) were immunized at 2 weeks intervals by three injections of reduced murine rTNFo (Immungenex, Los Angeles, CA, USA) emulsified in adjuvant (Hunter Titermax; CytRx Co., Norcross, Germany): the first one with $50 \mu \mathrm{g}$, the second and the third with $25 \mu \mathrm{g}$. The animals were bled 2 weeks after the last injec- 
tion, and total immunoglobulins were obtained after precipitation with $40 \%$ saturation of ammonium sulphate. Purified murine polyclonal anti-TNF $\alpha(2.5 \mathrm{mg} / \mathrm{ml})$ was administered into the rat air pouches in a volume of $0.7 \mathrm{ml}, 0.5 \mathrm{~h}$ before LPS. Control animals were treated under same conditions with the same amounts of preimmune immunoglobulins.

\section{Macrophage replenishment}

Rats were anaesthetized (sodium penthiobarbitone, $60 \mathrm{mg} / \mathrm{kg}$, i.p.), the trachea was cannulated and broncho-alveolar lavages (BAL) with sterile saline under a volume of $6 \mathrm{ml}$ were performed. This procedure was repeated until a final volume of $36 \mathrm{ml}$ was obtained in a $50 \mathrm{ml}-$ polypropylene graduated conical tube (Falcon ${ }^{(}$ 2098, Blue Max, sterile/gamma irradiated) on ice bath. Immediately after centrifugation $\left(400 \mathrm{~g}, 5 \mathrm{~min}\right.$ at $\left.4^{\circ} \mathrm{C}\right)$, the cell suspension underwent an hypotonic lysis with sterile water to remove remaining erythrocytes. Then, cells were counted (Counter Coulter ${ }^{\circ}$ ) and the suspension was diluted to a final concentration of $10^{6}$ and $10^{4}$ cells per ml. Purity and viability were assessed by differential count and blue trypan dye exclusion, respectively.

In other experiments, rats were treated with cycloheximide i.p. $(1 \mathrm{mg} / \mathrm{kg}, 0.5 \mathrm{ml}) .^{25}$ Control animals received similar volumes of saline. After $2 \mathrm{~h}$, the animals were sacrificed with an overdose of penthiobarbitone and both groups underwent the same procedure to purify the alveolar macrophages.

\section{Liposome preparation and experimental design}

Multilamellar liposomes were prepared according to Van Rooijen and Van Nieuwmegen. ${ }^{26}$ In brief, $75 \mathrm{mg}$ dipalmitoylphosphatidylcholine and $11 \mathrm{mg}$ cholesterol were dissolved in chloroform in a round bottom flask. The thin film that formed on the walls after rotary evaporation at $45^{\circ} \mathrm{C}$ was dispersed by gentle shaking for $10 \mathrm{~min}$ in $10 \mathrm{ml}$ of PBS (pH 7.4), in order to prepare empty liposomes, and in $10 \mathrm{ml}$ of a solution of $2 \mathrm{~g}$ clodronate (dichloromethylene diphosphonate or $\mathrm{C}_{2} \mathrm{MDP}$ ) in $\mathrm{PBS}$, in order to prepare liposomes with encapsulated $\mathrm{C}_{2} \mathrm{MDP}$. The preparation was kept for $2 \mathrm{~h}$ at room temperature and sonicated four times for $5 \mathrm{~min}$ at $45^{\circ} \mathrm{C}$ in a waterbath $(50 \mathrm{~Hz})$ and kept at room temperature for a further $2 \mathrm{~h}$. Then, liposomes were filtered through $1.2-\mu \mathrm{m}$ Minisart $\mathrm{NML}$ filters (disposable syringe holders, sterile, pyrogenfree, hydrophilic, Sartorius, Germany) centri- fuged at $100000 \mathrm{~g}$ to $0.5 \mathrm{~h}$, finally resuspended in $5 \mathrm{ml} \mathrm{PBS}$ and kept at $4^{\circ} \mathrm{C}$.

Rats with 7-day-old air pouches were anaesthetized and injected into this preformed cavity with either $0.3 \mathrm{ml}$ liposome-encapsulated clodronate or $0.3 \mathrm{ml}$ liposome-encapsulated PBS (empty liposome) for $96 \mathrm{~h}$ before LPS stimulation as previously described.

In order to overcome the cell counter inability to differentiate the remaining injected liposomes and the LPS-recruited cells, $100 \mu \mathrm{l}$ aliquots of pouch washing were allowed to stretch on glass slides by cytocentrifugation. After a Diff-Quik ${ }^{\circledR}$ staining, the slides were observed under light microscope at magnification $\times 1000$. A differential leukocyte count was performed (neutrophil, eosinophil, mononuclear cell) taking account of the total fields observed. Thus, the data was expressed as the number of neutrophils per field.

\section{Materials}

Lipopolysaccharide from Escherichia coli strain O55: B5 was purchased from Difco (Detroit, M, USA); heparin from Choay (Paris, France); ketamine hydrochloride $\left(\operatorname{KETALAR}^{\odot}\right)$ stored at $4^{\circ} \mathrm{C}$ as a $100 \mathrm{mg} / \mathrm{ml}$ stock solution was from ParkeDavis (Courbevoie, France); sodium penthiobarbitone was from Sanofi Santé Animale (Libourne, France); compound 48/80, bovine serum albumin, tetrazolium salt (MTT), the histamine-receptor antagonist $\mathrm{Hl}$ pyrilamine maleate (mepyramine), dexamethasone phosphate, chloroform, dipalmitoylphosphatidylcholine and cholesterol were from Sigma (St Louis, MO, USA); PAF-receptor antagonist WEB 2170 was a kind gift of Boehringer Ingelheim (Germany), cycloheximide was from Merck (Darmstadt, Germany); Diff-Quik ${ }^{\circledR}$ kit was purchased from Baxter S.A. (Maurepas, France), clodronate disodium salt (dichloromethylene diphosphonate, $\mathrm{d}_{2} \mathrm{MDP}$ ) was a kind gift of Boehringer Mannheim GmbH (Germany); murine recombinant TNF $\alpha$ was purchased from Immungenex (Los Angeles, CA, USA); human recombinant TNFo was a kind gift of Dr G. R Adolf (Wien, Austria); WEHI-164 cells were a kind gift of Dr I. L. Bonta (Rotterdam, The Netherlands).

\section{Data analysis}

Experimental value are given as mean \pm SEM Statistical significance of differences between two means of data were evaluated by a Students's $t$-test for unpaired observations and $P$ values less than 0.05 were considered to be significant. 


\section{Results}

Dose-effect relationship induced by

LPS compared with compound $48 / 80$

LPS (2-2000 ng, $2 \mathrm{~h}$ ) induced a dose-dependent leukocyte recruitment (Fig. 1a) which was predominantly formed by neutrophils (LPS: $67 \pm 5.7 \%$ vs. control: $14.6 \pm 7.6 \%, P<0.001$, $n=5-7$ ) (Fig. 1b). The threshold dose of LPS for inducing a significant leukocyte infiltration was $20 \mathrm{ng}(P<0.05, n=7)$ which correlated with the enhancement of the neutrophil population at this dose $(P<0.01, n=7)$. Since leukocyte and neutrophil infiltration plateaued at $200 \mathrm{ng}$, this dose was chosen for further experiments. By contrast, compound 48/80 $(250 \mu \mathrm{g}, 2 \mathrm{~h})$ failed to elicit leukocyte infiltration, compared with the vehicle.

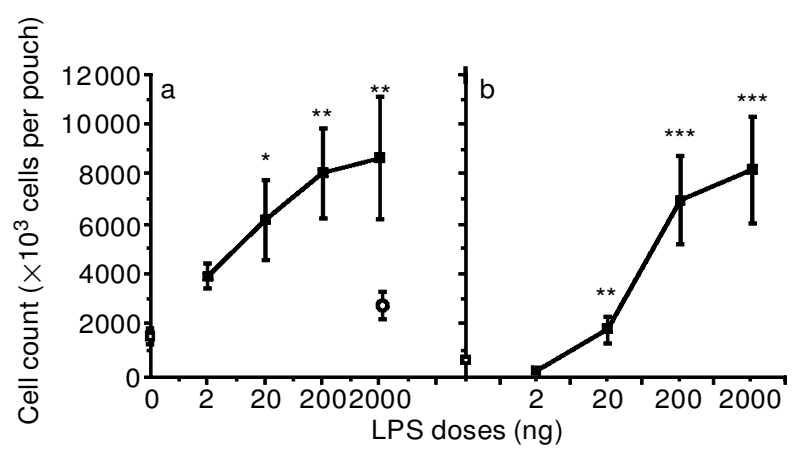

FIG. 1. Dose-dependent leukocyte and neutrophil recruitment induced by LPS ( $\square$ ) but not by compound 48/80 (O) into rat air pouches. LPS, at the doses of 2, 20, 200, $2000 \mathrm{ng}$ was injected under a volume of $1 \mathrm{ml}$ and samples removed at $2 \mathrm{~h}$. Compound $48 / 80$ at the dose of $250 \mu \mathrm{g}$ and PBS was tested under the same volume and at the same time-point. Responses are for (a) leukocyte and (b) neutrophil recruitment and are expressed as mean \pm SEM of total number of cells per pouch for leukocytes $(n=5-7)$ and neutrophils $(n=5-7)$ in LPS-treated animals $(\square)$ and in PBS-treated animals $(\square)\left({ }^{*} P<0.05\right.$, ${ }^{* *} P<0.01$, *** $\left.P<0.001\right)$.
Time-course of leukocyte and neutrophil recruitment induced by LPS

Leukocyte recruitment by LPS (200 ng) peaked at $2 \mathrm{~h}$ and $24 \mathrm{~h}$ (Table 1$)(P<0.01, n=7)$ and was over at $48-96 \mathrm{~h}$. Since at $2 \mathrm{~h}$ cell infiltration was predominantly constituted by neutrophils (Table 1) $(P<0.01, n=7)$, this time point was chosen for subsequent studies.

\section{Detection of TNF $\alpha$-like activity in supernatants of pouch}

Injected at the dose of $200 \mathrm{ng}(2 \mathrm{~h})$, LPS induced the generation of a significant TNFolike activity detected in the pouch washings $(P<0.01, n=5-9)$ under conditions where compound $48 / 80(250 \mu \mathrm{g} / \mathrm{ml}, 2 \mathrm{~h})$ failed to do so (Fig. 2).

\section{Interference of dexamethasone with LPS-induced neutrophil recruitment and $\mathrm{TNF} \alpha$-like activity, failure of mepyramine and WEB 2170}

Injected $2 \mathrm{~h}$ before LPS, dexamethasone (50$5000 \mathrm{ng}$ ) inhibited dose-dependently the LPSinduced recruitment of neutrophils $(P<0.01$ for the dose of $5000 \mathrm{ng}, n=7$ ) (Fig. 3). Accordingly, the threshold for inhibition was between 1000 and $2500 \mathrm{ng}$. By contrast, the H1-receptor antagonist mepyramine ( 1 and $4 \mathrm{mg} / \mathrm{kg}$, i.p., $0.5 \mathrm{~h}$ before LPS) and the PAF-receptor antagonist WEB $2170(0.05$ and $1 \mathrm{mg} / \mathrm{kg}$, i.p., $0.5 \mathrm{~h}$ before LPS) failed to interfere with the LPSinduced recruitment of neutrophils (Tables 2 and 3 ).

Injected $2 \mathrm{~h}$ before LPS, dexamethasone $(5000 \mathrm{ng})$ also inhibited the generation of TNF$\alpha$ like activity $(P<0.05, n=6)$ (Fig. 3, inset).

Table 1. Time-course of the LPS-induced leukocyte and neutrophil recruitment into rat air pouches. Leukocyte and neutrophil recruitment was evaluated at different time-points ( $2 \mathrm{~h}, 24 \mathrm{~h}, 48 \mathrm{~h}$ and $96 \mathrm{~h}$ ) for the dose of $200 \mathrm{ng}$ of LPS injected into the air pouches under a volume of $1 \mathrm{ml}$. Results are expressed as mean \pm SEM for $n=5-7$ experiments (** $P<0.01)$

\begin{tabular}{lcccc}
\hline & 2 & 24 & Time $(\mathrm{h})$ & 48 \\
& & & & 96 \\
\hline Leukocytes & & & \\
$\left(\times 10^{3}\right.$ cells $)$ & & & & \\
$\quad$ LPS & $8500 \pm 1970^{* *}$ & $7500 \pm 700^{* *}$ & $1000 \pm 120$ & $2730 \pm 60$ \\
$\quad$ Control & $1990 \pm 370$ & $3200 \pm 1300$ & $1470 \pm 140$ & $2500 \pm 680$ \\
Neutrophils & & & & \\
$\left(\times 10^{3}\right.$ cells $)$ & $7290 \pm 1840^{* *}$ & $1850 \pm 350^{* *}$ & $20 \pm 10$ & $260 \pm 70$ \\
LPS & $300 \pm 180$ & $310 \pm 160$ & 0 & $250 \pm 150$ \\
Control & & & & \\
\hline
\end{tabular}




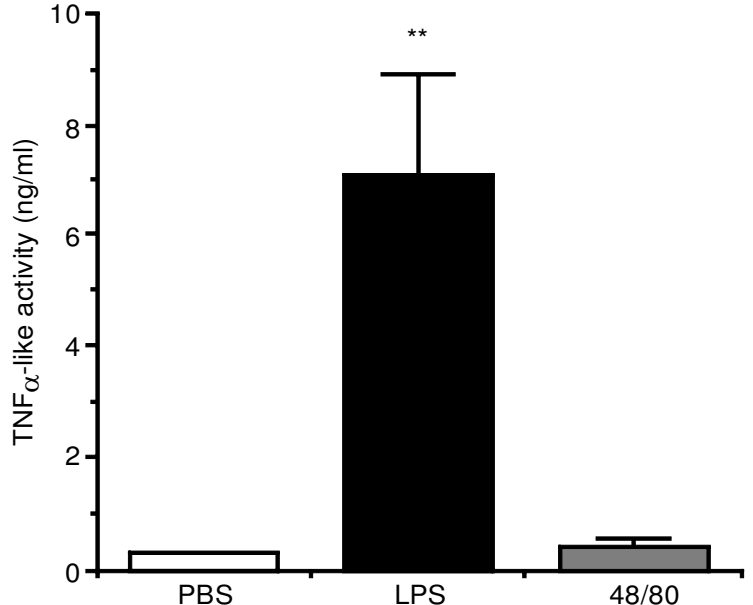

FIG. 2. Ability of LPS ( $200 \mathrm{ng}, 2 \mathrm{~h}$ ) and of compound $48 / 80$ $(250 \mu \mathrm{g}, 2 \mathrm{~h})$ to generate the TNF $\alpha$-like activity in the rat air pouch. The TNF $\alpha$-like activity was evaluated for LPS and compound 48/80 from the supernatants of pouch washing. Results are expressed as mean \pm SEM of TNF $\alpha$-like activity concentration for $n=4$ in the PBS group $(\square), n=9$ in the LPS group ( $\square$ ) and $n=5$ in the compound $48 / 80$ group ( $\square$ ). (*P<0.05, **P<0.01).

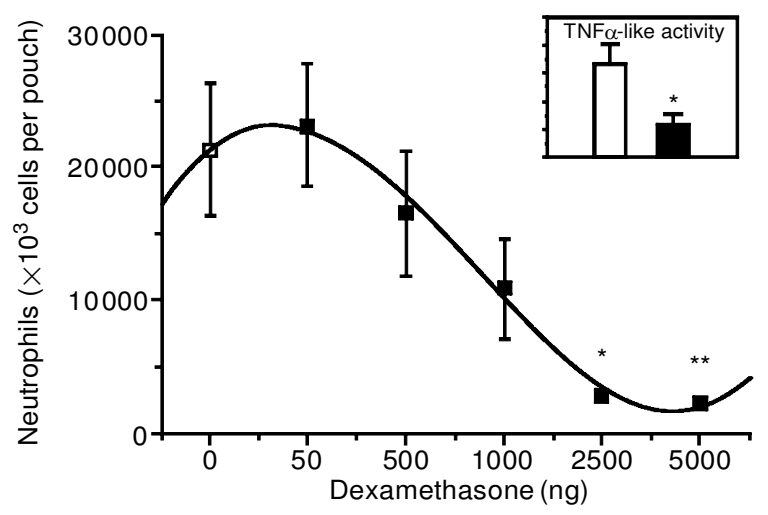

FIG. 3. Effects of dexamethasone (DEX) injected into the rat air pouches on neutrophil recruitment and TNF- $\alpha$ like activity induced by LPS. DEX at the doses of 50, 500, 1000, 2500 and $5000 \mathrm{ng}(\square)$ and the vehicle $(0 \mathrm{ng})(\square)$ were tested under a volume of $1 \mathrm{ml}, 2 \mathrm{~h}$ before LPS $(200 \mathrm{ng}, 2 \mathrm{~h}$ ). Neutrophil responses are expressed as mean \pm SEM of $5-7$ animals per dose. TNF- $\alpha$ like activity (inset) was assessed for the dose of $5 \mu \mathrm{g}$ and expressed as mean \pm SEM of TNF$\alpha$ like activity concentrations recovered in the air pouch washing supernatants for 5 animals $\left({ }^{*} P<0.05\right.$, $\left.{ }^{* *} P<0.01\right)$.

Table 2. Failure of mepyramine on LPS-induced recruitment of leukocytes and neutrophils into rat air pouches. The effects of mepyramine ( 1 and $4 \mathrm{mg} / \mathrm{kg}$, i.p., $0.5 \mathrm{~h}$ before LPS) on neutrophil recruitment were evaluated for the dose of $200 \mathrm{ng}$ of LPS ( $2 \mathrm{~h}$, into the pouches). Results are expressed as mean \pm SEM of total number of cells per pouch for $n=5$ experiments. No result was statistically different from the control group

\begin{tabular}{cccc}
\hline & $\begin{array}{c}\text { Mepyramine } \\
(4 \mathrm{mg} / \mathrm{kg})\end{array}$ & $\begin{array}{c}\text { Mepyramine } \\
(1 \mathrm{mg} / \mathrm{kg})\end{array}$ & $\begin{array}{c}\text { Control } \\
(\text { Saline })\end{array}$ \\
\hline $\begin{array}{c}\text { Leukocytes } \\
\left(\times 10^{3} \text { cells }\right)\end{array}$ & $5500 \pm 1400$ & $8850 \pm 2690$ & $5440 \pm 900$ \\
$\begin{array}{c}\text { Neutrophils } \\
\left(\times 10^{3} \text { cells }\right)\end{array}$ & $5070 \pm 1390$ & $8820 \pm 2400$ & $5080 \pm 880$ \\
\hline
\end{tabular}

Table 3. Failure of WEB 2170 to inhibit LPS-induced recruitment of leukocytes and neutrophils into rat air pouches. The effects of WEB $2170(0.05$ and $1 \mathrm{mg} / \mathrm{kg}$, i.p., $0.5 \mathrm{~h}$ before LPS) were evaluated for the dose of $200 \mathrm{ng}$ of LPS $(2 \mathrm{~h}$, into the pouches). Results (mean \pm SEM of total number of cells per pouch, $n=5$ ) of each single experiment are reported. No result was statistically different from the control LPS group

\begin{tabular}{cccc}
\hline & $\begin{array}{c}\text { WEB 2170 } \\
(50 \mathrm{mg} / \mathrm{kg})\end{array}$ & $\begin{array}{c}\text { WEB 2170 } \\
(1 \mathrm{mg} / \mathrm{kg})\end{array}$ & $\begin{array}{c}\text { Control } \\
(\text { Saline })\end{array}$ \\
\hline $\begin{array}{c}\text { Leukocytes } \\
\left(\times 10^{3} \text { cells }\right)\end{array}$ & $10600 \pm 1230$ & $11900 \pm 2600$ & $10300 \pm 2800$ \\
$\begin{array}{c}\text { Neutrophils } \\
\left(\times 10^{3} \text { cells }\right)\end{array}$ & $7700 \pm 1760$ & $8900 \pm 2800$ & $8900 \pm 2400$ \\
\hline
\end{tabular}

Interference of cycloheximide with LPS-induced neutrophil recruitment and generation of TNF $\alpha$-like activity

Injected into the pouch at $6 \mathrm{ng}, 2 \mathrm{~h}$ before $200 \mathrm{ng}$ of LPS, cycloheximide inhibited significantly the LPS-induced neutrophil recruitment (Fig. 4) $(P<0.01, n=5)$, but it was inactive, when injected together with LPS $(P>0.05$, $n=5)$. Similarly, cycloheximide interfered with the TNFatike activity generated by LPS (Fig. 4, inset) $(P<0.05, n=5)$.

\section{Replenishment of cycloheximide-} treated pouches with alveolar macrophage (AM) restores the LPSinduced recruitment of neutrophils and the accompanying generation of TNF $\alpha$-like activity

Alveolar macrophages (AM) (purity: 90\% viability: 95\%) were adjusted to a final concentration

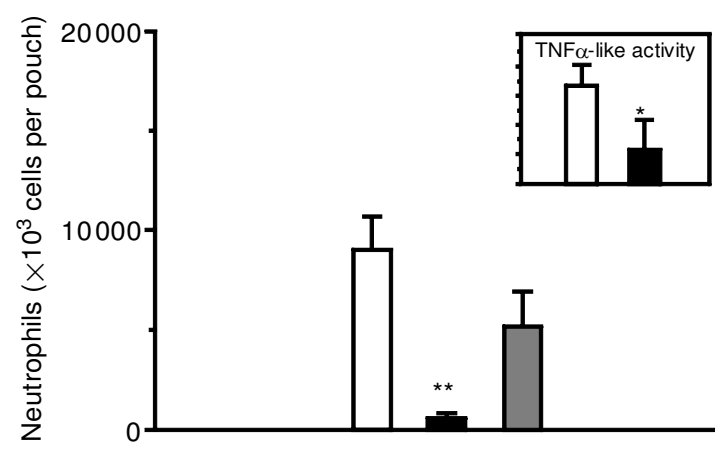

FIG. 4. Interference of cycloheximide (6 ng) injected into the rat air pouch $2 \mathrm{~h}$ before LPS with both neutrophil recruitment and TNF- $\alpha$ like activity. Cycloheximide was injected under a volume of $1 \mathrm{ml}$ with PBS, either $2 \mathrm{~h}$ before or together with LPS $(200 \mathrm{ng})$. Responses are for neutrophils and TNF- $\alpha$ like activity (box). Results are expressed as mean \pm SEM of total number of cells per pouch $(n=5)$ for the recruitment and of TNF- $\alpha$ like activity concentrations recovered in the air pouch washing supernatants for $n=5$. Cycloheximide-treated animals, $2 \mathrm{~h}$ befere LPS ( $\square$ ), together with LPS $\square$ ) and vehicle-treated animals $(\square)\left(^{*} P<0.05\right.$, $* * P<0.01)$. 
of $10^{6}$ and $10^{4}$ cells per $\mathrm{ml}$ and injected into the air pouch previously treated with cycloheximide ( $6 \mathrm{ng}$ per pouch, $2 \mathrm{~h}$ before). This replenishment restored significantly the LPS-induced neutrophil recruitment when compared with cycloheximide-treated pouches or with PBS stimulation (Fig. 5). In addition, replenishment with $10^{4} \mathrm{AM}$ per $\mathrm{ml}$ from cycloheximide-treated animals failed to support the LPS-induced

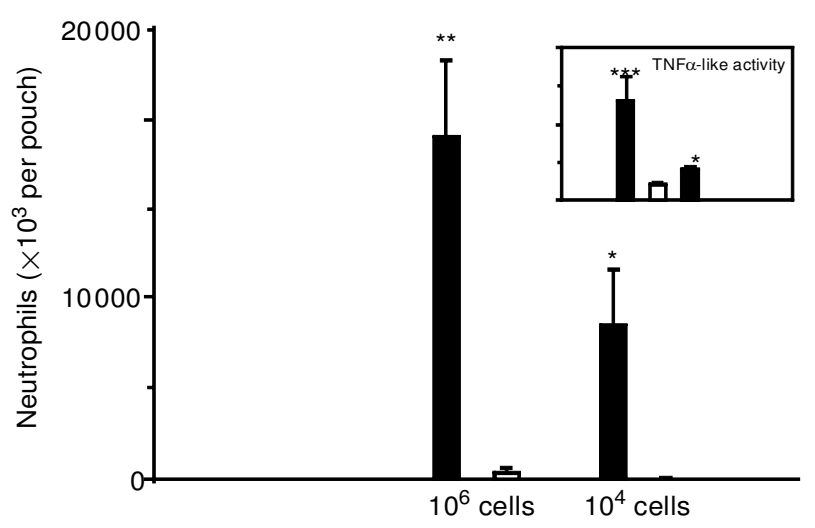

FIG. 5. Effects of replenishment with alveolar macrophages on LPS-induced recruitment of neutrophils and TNF- $\alpha$ like activity in rat air pouches. For the recruitment, air pouches were pretreated with $6 \mathrm{ng}$ of cycloheximide for $2 \mathrm{~h}$, then replenished with $10^{6}$ macrophages for four animals or with $10^{4}$ macrophages for six animals under a volume of $1 \mathrm{ml}$ for $0.5 \mathrm{~h}$, then stimulated with LPS (200 ng) or PBS for $2 \mathrm{~h}$ under a volume of $1 \mathrm{ml}$. Results are expressed as mean \pm SEM of total number of cells. For the TNF- $\alpha$ like activity (inset), the same conditions were used and results are expressed as mean \pm SEM of this activity recovered in the air pouch washing supernatants. Comparison for each replenishment group was performed for LPS $(\square)$ vs. PBS

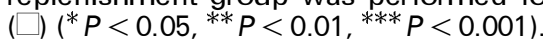

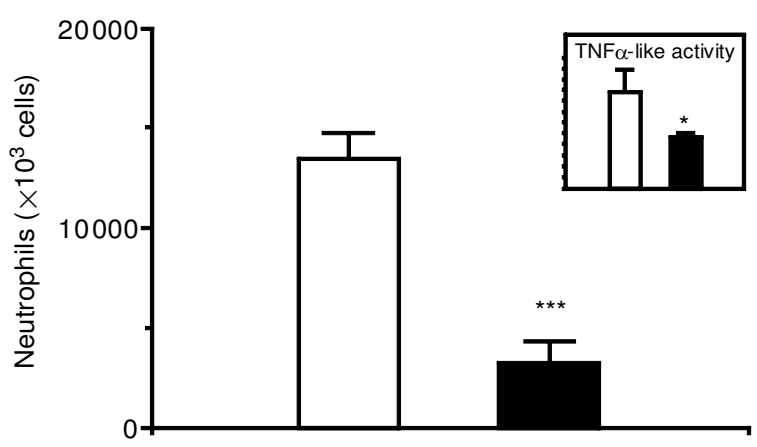

FIG. 6. Effects of cycloheximide (CHX) $(1 \mathrm{mg} / \mathrm{kg}$, i.p. $2 \mathrm{~h}$ before LPS) with the restoration of LPS-induced neutrophil recruitment and of following replenishment with alveolar macrophages in rat air pouches. Animals were treated with $\mathrm{CHX}$ or its vehicle, i.p. for $2 \mathrm{~h}$ before bronchoalveolar lavage. Replenishment was performed with $10^{4}$ macrophages $(1 \mathrm{ml})$ for $0.5 \mathrm{~h}$, then LPS or PBS stimulation were tested $(200 \mathrm{ng}, 2 \mathrm{~h}, 1 \mathrm{ml}$ ). Results are expressed as mean \pm SEM of total number of cells for $n=6$ experiments for the recruitment and of the TNF $\alpha$-like activity (inset) recovered in the air pouch washing supernatants for $n=6$ under the same conditions. Comparison was performed for $\mathrm{CHX}$ ( vs. its vehicle $(\square)\left({ }^{* *} P<0.01\right.$, $\left.{ }^{* * *} P<0.001\right)$. neutrophil recruitment (Fig. 6), contrasting to AM from control animals $(P<0.001$ for neutrophils, $n=6$ ).

Replenishment with $10^{6} \mathrm{AM} / \mathrm{ml}$ also restored the generation by LPS of TNFo-like activity in the pouch. Indeed, the replenished animals generated $13.02 \pm 3 \mathrm{ng} / \mathrm{ml}$ of TNFa-like activity upon LPS injection, whereas cycloheximidetreated animals generated $2.4 \pm 2.4 \mathrm{ng} / \mathrm{ml}$ $(n=5 ; P<0.05)$ (Fig. 5, inset). By contrast, replenishment with $10^{4} \mathrm{AM} / \mathrm{ml}$ generated $4.06 \pm 0.4 \mathrm{ng} / \mathrm{ml}$ of TNFa-like activity, a value not significant different from that obtained with AM from cycloheximide-treated animals (Fig. 6, inset).

\section{Interference of liposome-}

encapsulated clodronate with LPSinduced neutrophil recruitment and generation of TNF $\alpha$-like activity in rat air pouches

Liposome-encapsulated clodronate, injected into the rat air pouches $(300 \mu \mathrm{l}, 96 \mathrm{~h}$ before LPS), produced a marked inhibition of LPSinduced neutrophil emigration (Fig. 7) and generation of TNFo-like activity (Fig. 7, inset) in rat air pouches, when compared with empty liposomes (control: $57.1 \pm 11.9$ neutrophils per field; $20.6 \pm 13 \mathrm{ng} / \mathrm{ml}$ TNFo-tike activity; treated: $10.3 \pm 1.7$ neutrophils per field; $2.4 \pm$ $0.5 \mathrm{ng} / \mathrm{ml}$ TNFalike activity; $n=5-6, \quad P<$ 0.01 and $P<0.01$ respectively).

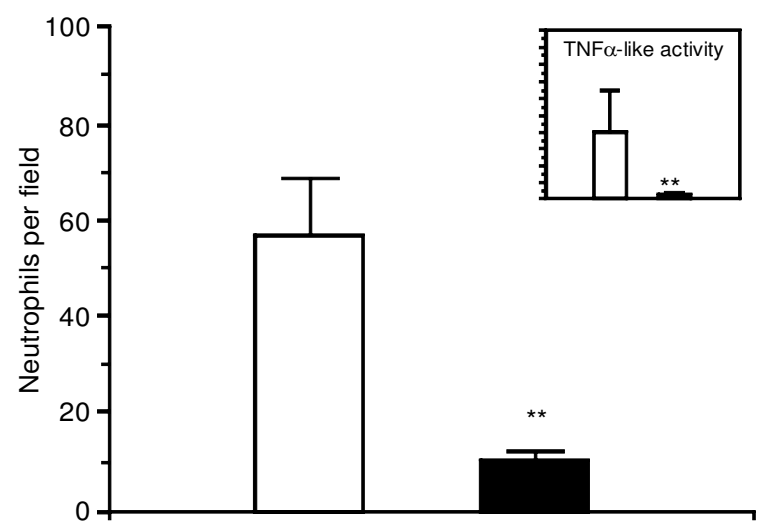

FIG. 7. Effects of liposome-encapsulated clodronate on neutrophil recruitment and the TNF- $\alpha$ like activity triggered by LPS in Brown Norway rat air pouches. Liposomeencapsulated clodronate and empty liposomes were administered under a volume of $0.3 \mathrm{ml}$ into the 7-day-old air pouches, $96 \mathrm{~h}$ before LPS $(200 \mathrm{ng}, 2 \mathrm{~h})$. Results are expressed as mean \pm SEM of number of neutrophils per field $(n=6)$ and of the TNF- $\alpha$ like activity recovered in the air pouch washing supernatants $(n=6)$ (inset). Comparison was performed for liposome-encapsulated clodronate ( vs. empty liposome ( $\square$ ( ${ }^{* *} P<0.01$; $\left.{ }^{* * *} P<0.001\right)$. 
Anti-mouse TNF $\alpha$ polyclonal antibodies suppressed the LPSinduced neutrophil recruitment and the generation of $\mathrm{TNF}_{\alpha}$-like activity in rat air pouches

Under conditions where both LPS-induced neutrophil recruitment and TNFatike activity were significantly inhibited by anti-mouse TNFa polyclonal antibody $(0.7 \mathrm{ml}$ into the pouch, $0.5 \mathrm{~h}$ before LPS), a treatment with non-immune polyclonal antibodies was uneffective (control: $15611 \pm 423610^{3}$ neutrophils vs. treated: $3888 \pm 41110^{3}$ neutrophils, $P<0.05$ (Fig. 8); control: $7.3 \pm 1.2 \mathrm{ng} / \mathrm{ml}$ of TNFa-like activity vs. treated: $0.11 \pm 0.08 \mathrm{ng} / \mathrm{ml}$ of TNFatike activity, $P<0.01$ (Fig. 8 , inset; for $n=4$ animals).

\section{Discussion}

The injection of LPS into the rat air pouch resulted in a potent time- and dose-dependent recruitment of neutrophils. Suppression of this recruitment by low amounts of the protein synthesis inhibitor cycloheximide and by dexamethasone, injected into the pouch, suggested the involvement of a local target, capable of producing a secondary mediator. Since the concomitant injection of cycloheximide and LPS failed to block neutrophil recruitment, the $2 \mathrm{~h}$ interval required for inhibition is probably

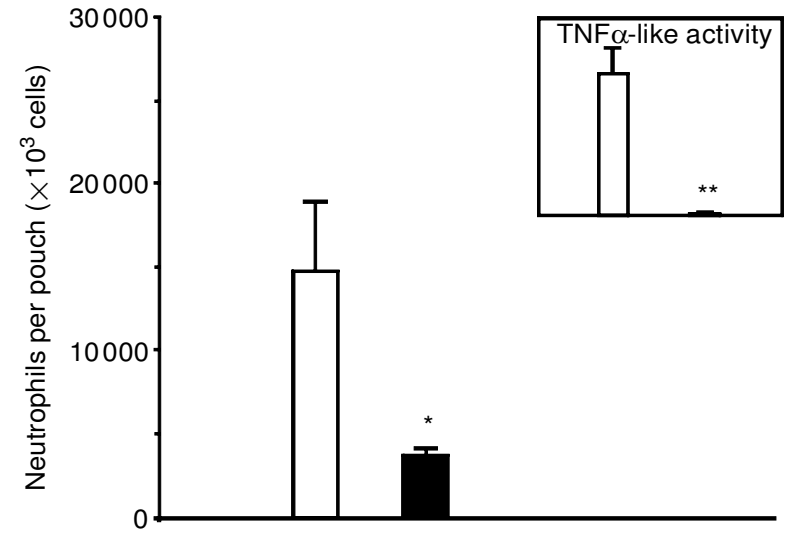

FIG. 8. Effects of the mouse polyclonal anti-TNF $\alpha$ antibody with neutrophil recruitment and TNF $\alpha$-like induced by LPS. Results are expressed as mean \pm SEM of total number of neutrophils per pouch and of TNFo-like activity concentrations recovered in the air pouch washing supernatants. The treated group received into their pouch $0.7 \mathrm{ml}$ of the polyclonal antibody for $0.5 \mathrm{~h}$, then LPS $(\square)$. The control group was treated with a non-immune antibody preparation under same conditions ( $\square$ ). Results are expressed as mean \pm SEM of total number of cells for four experiments for the recruitment and of the TNF- $\alpha$ like activity (inset) recovered in the air pouch washing supernatants for four experiments. Comparison was performed for treated group ( $\square$ ) vs. control group $(\square)\left({ }^{*} P<0.05\right.$, $\left.{ }^{* *} P<0.01\right)$.

accounted for by the time needed for inhibition of protein synthesis. Alternatively, cycloheximide may induce apoptosis, ${ }^{27,28}$ an active process requiring protein and RNA synthesis ${ }^{29}$ and involving the degradation of nuclear $\mathrm{DNA}^{30}$ Although apoptosis is prevented in most cells
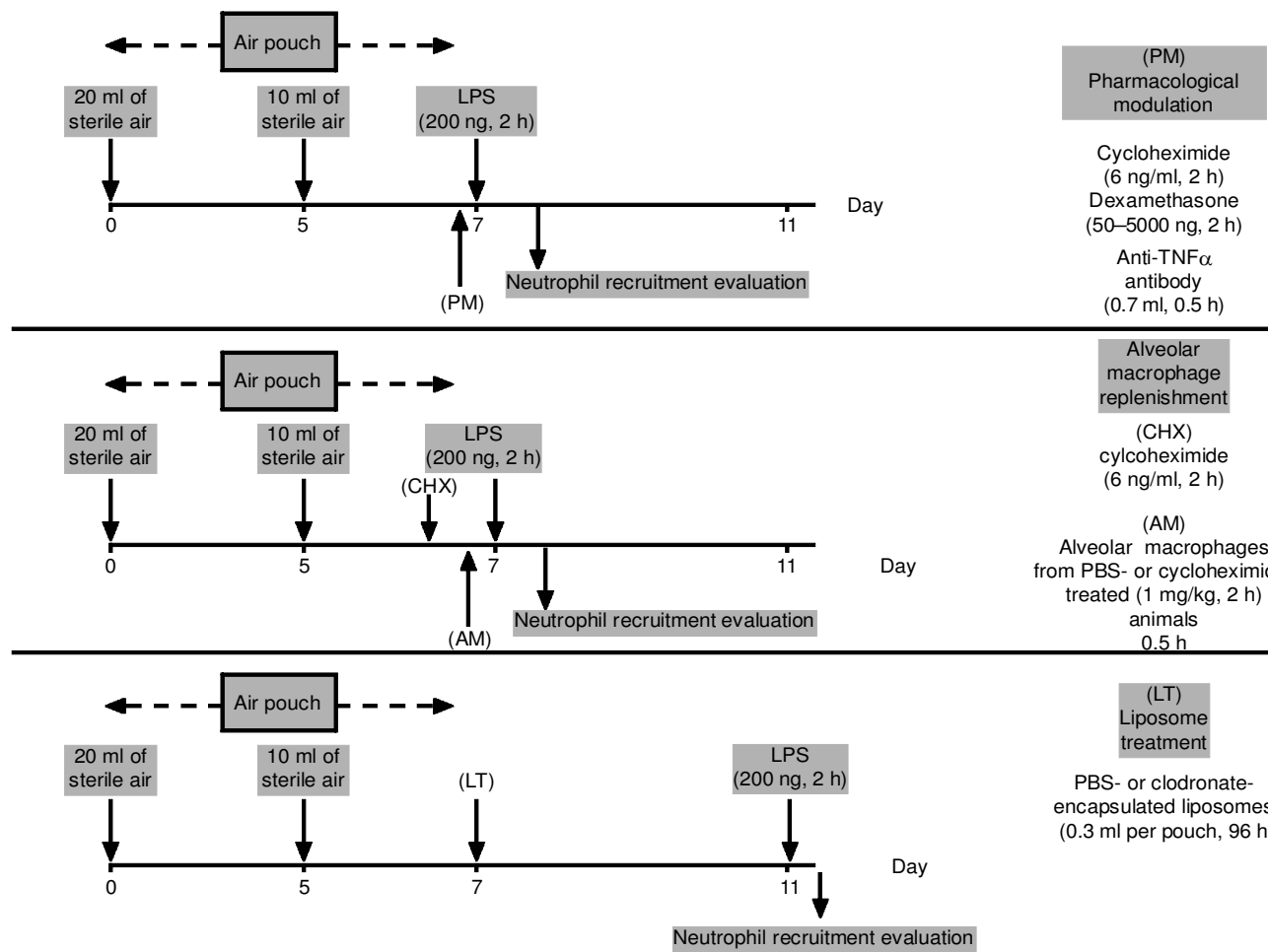

Alveolar

macrophage

(CHX)

cylcoheximide

$(6 \mathrm{ng} / \mathrm{ml}, 2 \mathrm{~h})$

(AM)

Alveolar macrophages

from PBS- or cycloheximide

treated $(1 \mathrm{mg} / \mathrm{kg}, 2 \mathrm{~h})$ animals 
by cycloheximide, HL-60 cells, ${ }^{31}$ hepatocytes, ${ }^{25,27}$ thymocytes and macrophages ${ }^{28}$ undergo apoptosis when incubated with micromolar doses of this drug. However, apoptosis is unlikely to account for the suppression of neutrophil recruitment in our experiments, since the conditions used here $(2 \mathrm{~h}, 6 \mathrm{ng} \approx$ $200 \mathrm{nmol}$ ) were previously shown not to induce apoptosis. ${ }^{28}$

Resident mast cells might be affected by cycloheximide and by dexamethasone during LPS-induced neutrophil emigration, as suggested by the results of Matsuda et al. ${ }^{24}$ with murine air blebs, a model closely resembling an air pouch but lacking a facsimile synovium. Similarly, Tannenbaum et al.,32 injected compound 48/80 into the rat skin at doses 50 times below ours and provoked a marked neutrophilia within 1-2 h. Compound 48/80 also caused mast cell degranulation, neutrophil adhesion and emigration into the cheek pouch vasculature. ${ }^{33}$ Nevertheless, mast cell involvement is unlikely in our model, since the compound 48/80 failed to induce a significant cell infiltration or generation of TNFatike activity, throughout all time intervals. A more likely hypothesis is that fibroblasts and macrophages of the pouch lining tissue account for the LPS-induced production of chemotactic substances and the consequent neutrophil recruitment, in agreement with the anatomopathological studies of Edwards et al..$^{22}$ To verify to what extent this might apply to our model, alveolar macrophages were used to replenish the air pouch and indeed inhibition by cycloheximide of neutrophil emigration and generation of TNFatike activity, was surmounted by transferring fresh alveolar macrophages from control animals, whereas macrophages from cycloheximide-treated animals were not effective, as reported. ${ }^{12,34}$ The use of alveolar macrophages rather than other sources of macrophages is supported by practical considerations concerning macrophage purification and their ability to provide large amounts of $\mathrm{TNF}^{35}$ or chemoattractants such as $\mathrm{MP}-1 \alpha^{36}$

Liposomes are particularly efficient in delivering water-soluble drugs into phagocytic cells, since phagocytosis is followed by phospholipase-induced disruption of the liposome phospholipid bilayers and the release of entrapped drugs. In particular, liposomeencapsulated clodronate which should deplete air pouch macrophages ${ }^{37,38}$ reduced significantly LPS-induced neutrophil recruitment. Since in separate experiments murine peritoneal macrophages were still absent after 5 days treatment (data not shown), the participation of the air pouch macrophage during neutrophil emigration is thus likely. Codronate is specific for macrophages, since it neither affected the neutrophil population nor other cell types. $37,39,40$

Since a potential role for histamine and PAF in LPS-induced neutrophil recruitment into rat air pouches was excluded by selective antagonists, the effectiveness of cycloheximide and dexamethasone strongly suggests the involvement of protein synthesis-dependent mediators such as $\mathrm{TNF} \alpha$. As mentioned, the hypothesized participation of mast cells as a major source of preformed $\mathrm{TNF}^{41}$ was ruled out by the failure of compound 48/80 to induce neutrophil recruitment and detectable TNFa-like activity. Among cells that express the TNF gene, the macrophage is unique, insofar as it is capable of secreting-1000 times more TNFo in response to LPS than any other cell type. ${ }^{42,43}$ Furthermore, a TNFo-like activity was detected in the air pouch transplanted with alveolar macrophages from naive, but not from cycloheximide-treated animals. In addition, the rat alveolar macrophage was shown to be an important producer of chemoattractants when stimulated by LPS. ${ }^{44}$ Taken together, these results suggest that TNF $\alpha$ like activity accounts for the LPS-induced neutrophil recruitment in our model. This was supported by the efficacy of an anti-murine polyclonal TNF $\alpha$ antibody to abrogate both LPStriggered neutrophil recruitment and TNFo-tike activity. The resident macrophage is the likely source of this cytokine, as its formation was prevented by both in situ treatments with liposome-encapsulated clodronate and polyclonal antibody. Nevertheless, our results do not clarify whether TNF $\alpha$ acts as a direct chemoattractant to promote neutrophil emigration or if an intermediary chemokine is required, such as CINC/ GRO or MP-1 or 2. Indeed, even though $\mathrm{TNF} \alpha$ itself may increase adhesion molecules such as $\mathrm{CD1} 1 / 18$ to promote neutrophil emigration, ${ }^{45}$ several studies seem to plead for a chemokine networking involving either epithelial cell ${ }^{46}$ or endothelial cell. ${ }^{47}$

In summary, we suggest that neutrophil recruitment induced by LPS is a macrophagedependent event, involving the de novo synthetized TNF $\alpha$ which act directly or via secondary mediators.

\section{References}

1. Issekutz AC, Bhimji S. Role of endotoxin in the leukocyte infiltration accompanying Escherichia coli inflammation. Infect Immun 1982; 36: 558.

2. Cybulsky MI, McComb DJ, Movat HZ. Neutrophil leukocyte emigration induced by endotoxin. Mediator roles of IL-1 and TNFa. J Immunol 1988; 140: $3144-3149$. 
3. Hugli T. Chemotaxis. Curr Opin Immunol 1989; 2: 19-27.

4. Wright SD, Ramos RA, Hermanowski A, Rockwell P, Detmers PA Activation of the adhesive capacity of CR3 on neutrophils by endotoxin: dependence on lipopolysaccharide binding protein and CD14. J Exp Med 1991; 173: 1281-1286.

5. Weingarten R, Sklar LA, Mathison JC, Omidi S, Ainsworth T, Simon S, Ulevitch RJ, Tobias PS. (1993) Interactions of lipopolysaccharide with neutrophils in blood via CD14. J Leukoc Biol 1993; 53: 518 -524.

6. Manthey CL Vogel SN. Interaction of lipopolysaccharide with macrophages. In: Zwilling BS, Eisenstein TK (eds) Macrophage-Pathogen Interactions. New York-Basel-Hong Kong: Marcel Dekker, 1994: 6381.

7. Wahl LM, Wahl SM, Mergenhagen SE, Martin GR Collagenase production by endotoxin activated macrophages. Proc Natl Acad Sci USA 1974; 71: $3598-3601$

8. Feuerstein G, Hallenbeck JM, Vanatt AB, Rabinovici R, Perera PY, Vogel $\mathrm{SN}$. Effect of gram-negative endotoxin on levels of serum corticoster one, TNFa, circulating blood cells, and the survival of rats. Circ Shock 1990; 30: $265-278$.

9. Klosterhafen B, Horstmenn-Jungemann K, Vogel P, Flohe S, Offner F Kirckpatrick C, Heinrich PC. Time course of various inflammatory mediators during recurrent endotoxaemia. Biochem Pharm acol 1992; 43: $2103-2109$.

10. Mason MI, Van Epps DE. In vivo neutrophil emigration in response to interleukin-1 and tumor necrosis factor. J Leukoc Biol 1989; 45: 62 68.

11. Rampart MWDS, Fiers W, Herman AG. Inflammatory properties of recombinant tumor necrosis factor in rabbit skin in vivo. $J$ Exp Med 1989; 169: $2227-2232$.

12. Harmsen AG, Havell EA. Roles of tumor necrosis factor and macrophages in lipopolysaccharide-induced accumulation of neutrophils in cutaneous air pouches. Infect Im mun 1990; 58: 297-302.

13. Klebanoff SJ, Vadas MA, Harlan JM, Sparks LH, Gamble JR, Agosti JM Waltersdorph AM Stimulation of neutrophils by tumor necrosis factor. J Imm unol 1986; 136: 4220.

14. Tsujimoto M, Yokota S, Vilceck J, Weismann G. Tumor necrosis facto provokes superoxide anion generation from neutrophils. Biochem Biophys Res Commun 1986; 137: 1094.

15. Gamble JR, Harlan JM, Klebanoff SJ, Vadas MA. Stimulation of the adherence of neutrophils to umbilical vein endothelium by human recombinant tumor necrosis factor. Proc Natl Ac ad Sci USA 1985; 82 8667.

16. Ulich TR, Guo K, Del Castillo J. Endotoxin induced cytokine gene expression in vivo. Am J Pathol 1989; 134: $11-14$

17. Beutler BA, Cerami AJ. Cachectin and tumor necrosis factor as two sides of the same biological coin. Nature (Lond) 1986; 320: 584.

18. Ulich TR, Guo K, Irwin B, Remick DG, Davatelis GN. Endotoxin induced cytokine gene expression in vivo. II. Regulation of tumor necrosis factor and interleukin-1 $\alpha / \beta$ expression and suppression. $A m J$ Pathol 1990; 137: 1173-1185.

19. de Castro CMMB, Bureau M-F, Vargaftig BB, Bachelet M Interference of dexamethasone with leukocyte, blood volume and albumin movements in lungs from endotoxemics guinea-pigs. Pulm Pharm acol 1995; 8: $289-297$.

20. Ragsdale RL, Grasso RJ. An improved spectrofluorometric assay for quantifying yeast phagocytosis in cultures of murine peritoneal macrophages. J Imm unol Me tho ds 1989; 123: 259-267.

21. Waage A. Production and clearance of tumor necrosis factor in rats exposed to endotoxin and dexamethasone. Clin Immunol Immunopathol 1987; 45: $348-355$.

22. Edwards JCW, Sedgwick AD, Willoughby DA. The formation of structure with the features of synovial lining by subcutaneous injection of air: an in vivo tissue culture system. J Pathol 1981; 134: 147-156.

23. Weiss SJ. Tissue destruction by neutrophils. N Engl J Med 1989; 320: $365-375$.

24. Matsuda H, Kawakita K, Kiso Y, Nakano T, Kitamura Y. Substance P induces granulocyte infiltration through degranulation of mast cells. Imm unol 1989; 142: $927-931$.

25. Verbin RS, Goldblatt PJ, Farber E. The biochemical pathology of inhibition of protein synthesis in vivo: the effects of cycloheximide on hepatic parenchymal cell ultrastructure. Lab Invest 1969; 20: 529 536.

26. Van Rooijen N, Van Nieuwmegen R. Elimination of phagocytic cells in the spleen after intravenous injection of liposome-encapsulated dichloromethylene diphosphonate. An enzyme-histochemical study. Cell Tissue Res 1984; 238: 355-358.

27. Ledda-Columbano GM, Coni P, Faa G, Manenti G, Columbano A. Rapid induction of apoptosis in rat liver by cycloheximide. Am J Pathol 1992; 140: $545-549$.

28. Waring P. DNA fragmentation induced in macrophages by gliotoxin does not require protein synthesis and is preceded by raised inositol triphosphate levels. J Biol Chem 1990; 265: $14476-14480$.

29. Wyllie AH, Kerr JFR, Currie AR Cell death: the significance of apoptosis. Int Rev Cytol 1980; 68: 251-306.

30. Tepper CG, Studzinski GP. Teniposide induces nuclear but not mitochondrial DNA degradation. Cancer Res 1992; 52: $3384-3390$.

31. Gong J, Xun L, Darzynkiewicz Z. Different patterns of apoptosis of HL60 cells induced by cycloheximide and camptothecin. J Cell Physiol 1993; 157: $263-270$

32. Tannenbaum S, Oertel H, Henderson W, Kaliner M. The biologic activity of mast cell granules. I. Elicitation of inflammatory responses in rat skin. J Imm unol 1980; 125: 325-335.

33. Raud J, Dahlen SE, Smedegard G, Hedqvist P. An intra-vital microscopic model for mast cell-dependent inflammation in the hamster cheek pouch. Acta Physiol Sc and 1989; 135: 95-105.

34. Faccioli LH, Souza GEP, Cunha FQ, Poole S, Ferreira SH. Recombinant interleukin-1 and tumor necrosis factor induce neutrophil migration 'in vivo' by indirect mechanisms. Agents Actions 1990; 30: $344-349$

35. Tachibana K, Chen G-J, Huang DS, Scuderi P, Watson RR Production of tumor necrosis factor $\alpha$ by resident and activated murine macrophages. J Leukoc Biol 1992; 51: 251-255.

36. Van Otteren GM, Standiford TJ, Kunkel SL, Danforth JM, Burdick MD, Abruzzo LV, Strieter RM Expression and regulation of macrophage inflammatory- $1 \alpha$ by murine alveolar and peritoneal macrophages. $\mathrm{Am} J$ Respir Cell Mol Biol 1994; 10: 8-15.

37. Van Rooijen N, Kors N, Kraal G. Macrophage subset repopulation in the spleen: differential kinetics after liposome-mediated elimination. $J$ Leukoc Biol 1989; 45: $97-104$.

38. Van Rooijen N, Kors N, Ende M, Dijkstra CD. Depletion and repopulation of macrophages in spleen and liver of the rat after intravenous treatment with liposome-encapsulated dichloromethylene diphosphonate. Cell Tissue Res 1990: 260: 215-222.

39. Bogers WMJM, Stad R-K, Janssen DJ, Van Rooijen N, Van Es LA, Daha MR. Kuppfer cell depletion in vivo results in preferential elimination of IgG aggregates and immune complexes via specific $F_{c}$ receptors on rat liver endothelial cells. Clin Exp Immunol 1995; 86: 328.

40. Salkowski CA, Neta R, Wynn T, Strassman G, Van Rooijen N, Vogel SN Effect of liposome-mediated macrophage depletion on LPS-induced cytokine gene expression and radioprotection. J Im munol 1995; 155 $3168-3179$.

41. Gordon JR, Galli SJ. Mast cells as a source of both preformed and immunologically inducible TNFo/ cachectin. Nature (Lond) 1990; 346: $274-276$.

42. Matthews N. Tumor-necrosis factor from the rabbit. II. Production by monocytes. Br J Cancer 1978; 38: 310.

43. Beutler BA, Mulsark IW, Cerami A. Cachectin/tumor necrosis factor: production, distribution and metabolic fate in vivo. I Imm unol 1985; 135: $3972-3977$.

44. Chrisman JW, Petras SF, Vacek PM, Davis GS. Rat alveolar macrophage production of chemoattractants for neutrophils: response to Escherichia coli endotoxin. Infect Immun 1989; 57: 810 -816.

45. Windsor ACJ, Walsh CJ, Mullen PG, Cook DJ, Fisher BJ, Blocher CR, Leeper-Woodford SK, Sugerman HI, Fowler III AA. Tumor necrosis factor- $\alpha$ blockade prevents neutrophil CD18 receptor and attenuates acute lung injury in porcine sepsis without inhibition of neutrophil oxygen radical generation. J Clin Invest 1993; 91: 1459-1468.

46. Smart SJ, Casale TB. Pulmonary epithelial cells facilitate TNFo-induced neutrophil chemotaxis. J Im munol 1994; 152: $4087-4094$.

47. Furie MB, McHugh DD. Migration of neutrophils across endothelial monolayers is stimulated by treatment of the monolayers with IL-1 or tumor necrosis factor- $\alpha$. J Imm unol 1989; 143: 3309.

\section{Received 5 June 1997;} accepted in revised form 1 July 1997 


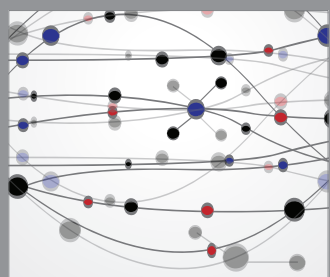

The Scientific World Journal
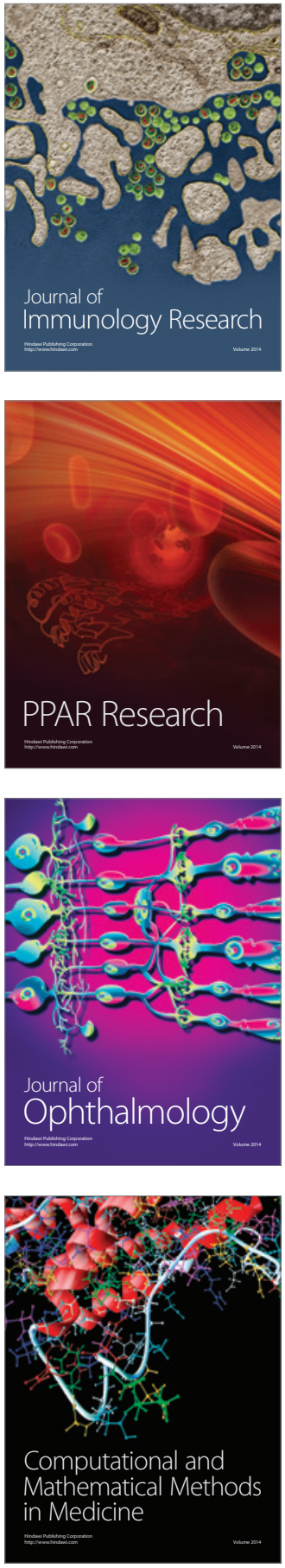

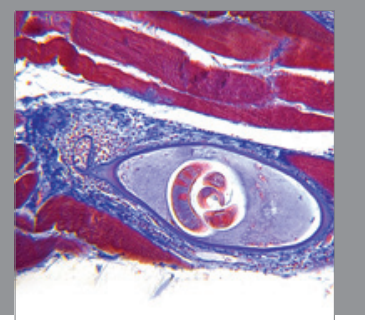

Gastroenterology

Research and Practice
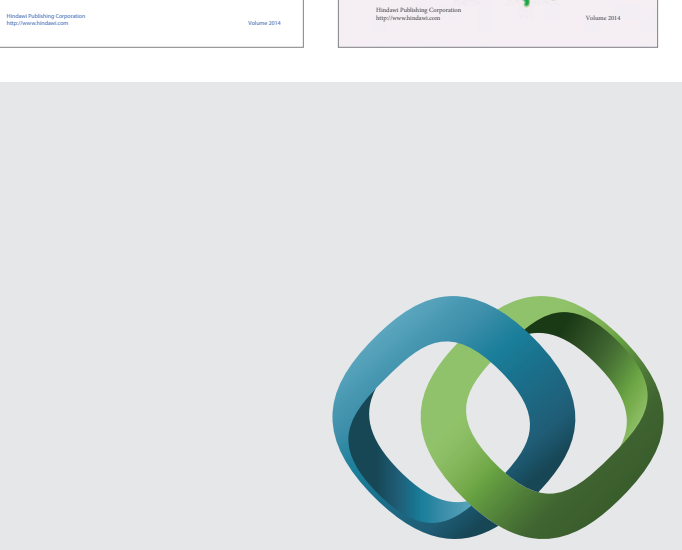

\section{Hindawi}

Submit your manuscripts at

http://www.hindawi.com
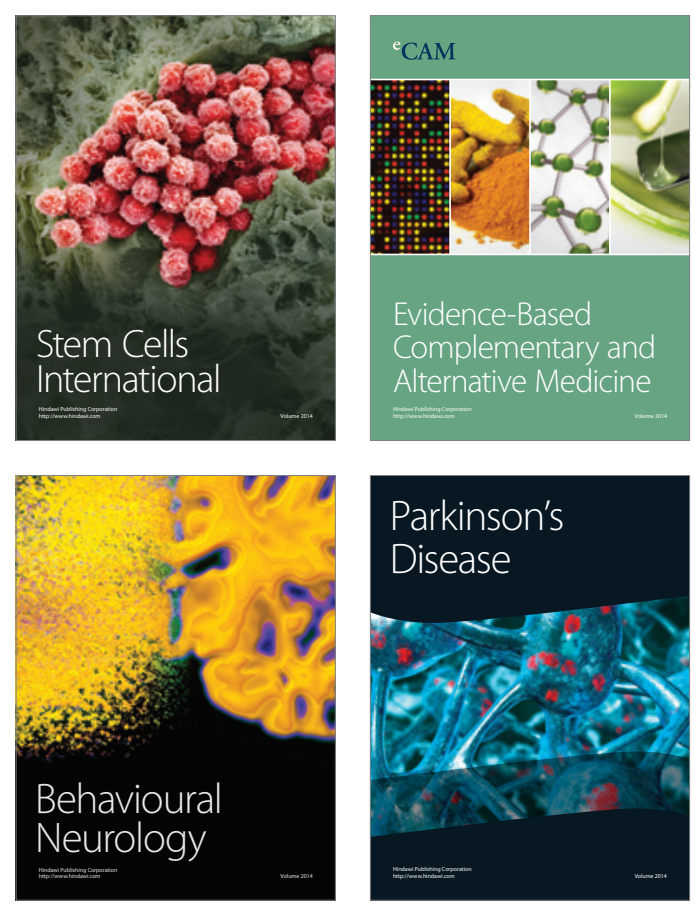

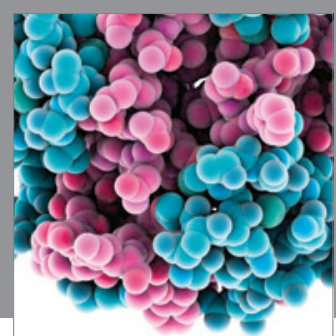

Journal of
Diabetes Research

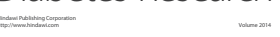

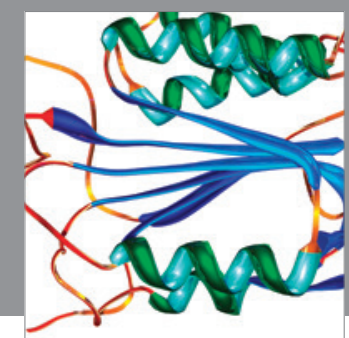

Disease Markers
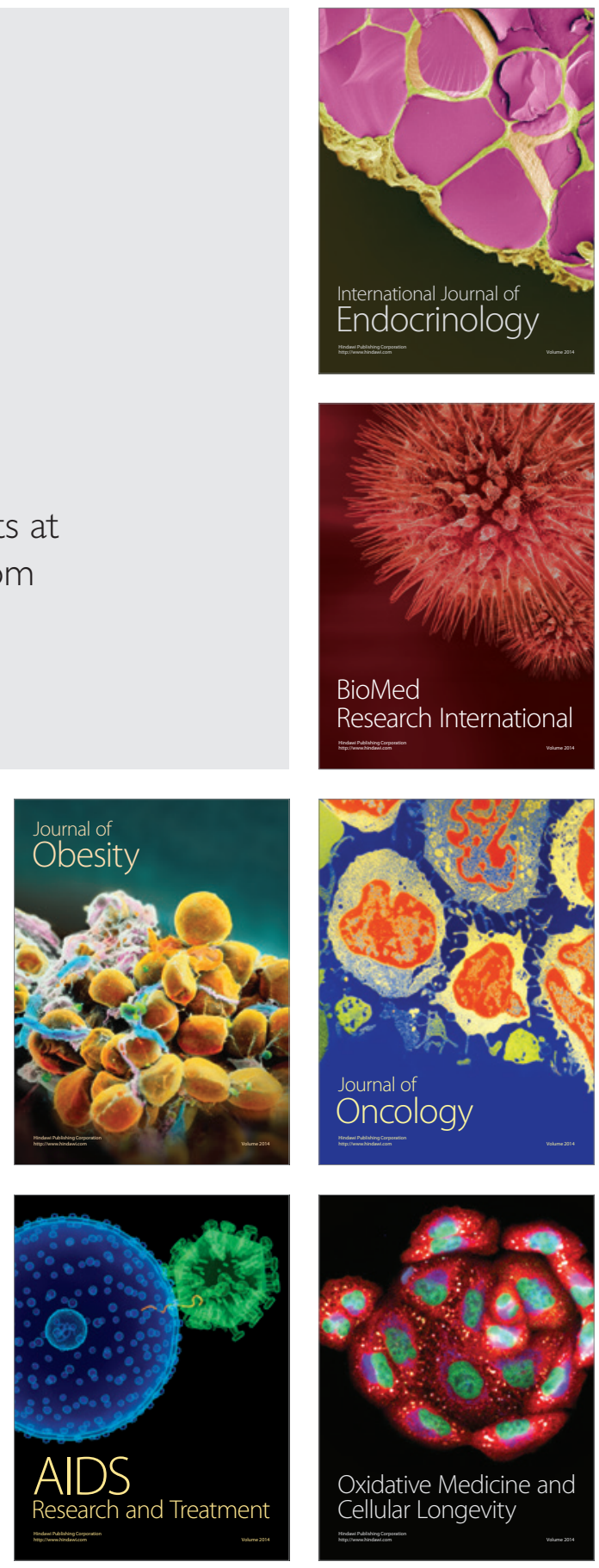